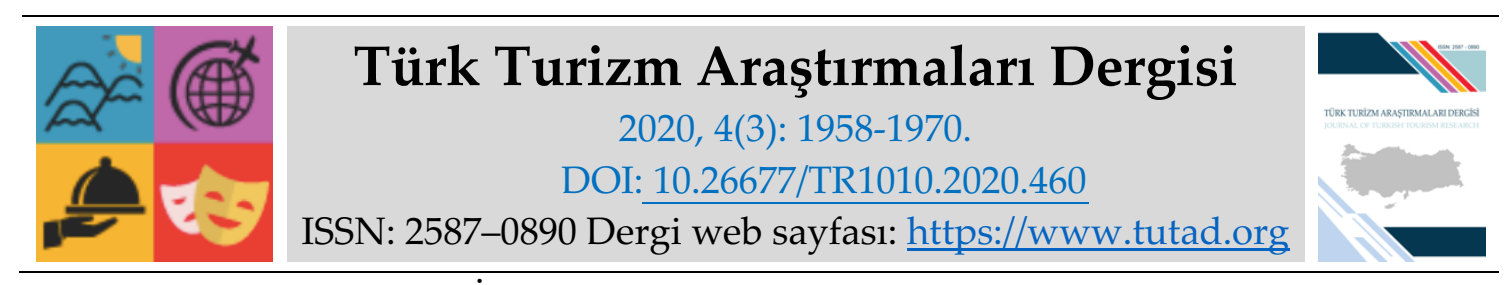

ARAȘTIRMA MAKALESİ

\title{
Turizm Öğrencilerinin Kültürlerarası Duyarlılık Düzeylerinin Tespitine Yönelik Karşılaştırmalı Bir Araştırma
}

Dr. Öğr. Üyesi Gencay SAATCI, Çanakkale Onsekiz Mart Üniversitesi, Turizm Fakültesi, Çanakkale, e-posta: gencaysaatci@comu.edu.tr ORCID: https://orcid.org/0000-0002-7842-989X

Dr. Öğr. Üyesi Serkan TÜRKMEN, Çanakkale Onsekiz Mart Üniversitesi, Turizm Fakültesi, Çanakkale, e-posta: sturkmen@comu.edu.tr ORCID: https://orcid.org/0000-0002-0921-6102

Öz

Turizm hizmet verenler ve hizmet alanlar açısından çok uluslu yapıya sahip bir sektördür. Özellikle başarılı bir hizmetin sunulması konusunda hizmet verenlerin iletişim becerilerinin çok iyi olması gerekmektedir. Farklı kültürden insanların bulunduğu ortamda iyi iletişim kurabilmek için kültürlerarası duyarlılık önemli bir rol oynamaktadır. Dolayısıyla turizm sektörü içerisinde, turizm fakültelerinde eğitim alan öğrencilerin başarılı olabilmeleri için kültürlerarası duyarlılık düzeylerinin tespit edilmesi ve geliştirilmesi oldukça önemlidir. Bu çalışmada Balıkesir ve Çanakkale illerinde bulunan turizm fakültelerinde öğrenim gören 530 öğrencinin kültürlerarası duyarlılıkları araştıılmıştır. Kültürlerarası duyarlılık ölçeği "kültürel farklılıklara sayg1", "etkileşimde kendine güvenme", "etkileşimden hoşlanma" ve "etkileşim sorumluluğu" olmak üzere dört boyutta ortaya çıkmıştır. Öğrencilerin en yüksek katılım gösterdikleri boyut "kültürel farklılıklara saygı" olurken; en düşük katılım gösterilen boyut ise "etkileşimde kendine güvenme" olmuştur.

Anahtar Kelimeler: Kültürlerarası Duyarlılık, Çanakkale, Balıkesir, Turizm Fakültesi.

Makale Gönderme Tarihi: 31.03 .2020

Makale Kabul Tarihi: 02.07.2020

\section{Önerilen Atıf:}

Saatcı, G. ve Türkmen, S. (2020). Turizm Öğrencilerinin Kültürlerarası Duyarlılık Düzeylerinin Tespitine Yönelik Karşılaştırmalı Bir Araştırma, Türk Turizm Araştırmaları Dergisi, 4(3): 19581970.

(c) 2020 Türk Turizm Araştırmaları Dergisi. 


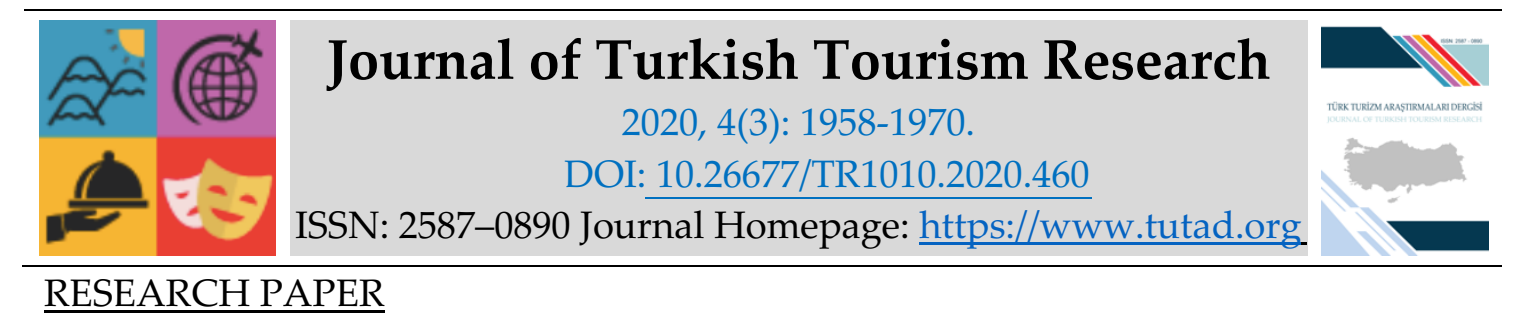

\title{
A Comparative Research on the Determination of Intercultural Sensitivity Levels of Tourism Students
}

Assistant Prof. Dr. Gencay SAATCI, Çanakkale Onsekiz Mart University, Faculty of Tourism, Çanakkale, e-mail: gencaysaatci@comu.edu.tr ORCID: https://orcid.org/0000-0002-7842-989X

Assistant Prof. Dr. Serkan TÜRKMEN, Çanakkale Onsekiz Mart University, Faculty of Tourism, Çanakkale, e-mail: sturkmen@comu.edu.tr ORCID: https://orcid.org/0000-0002-0921-6102

\begin{abstract}
Tourism is a multinational sector in terms of service providers and users. Especially in the provision of a successful service, communication skills of the service providers should be very good. Intercultural sensitivity plays an important role to communicate successfully in an environment with people from different cultures. Therefore, in order to be successful in tourism sector, it is very important to be determined and developed intercultural sensitivity levels for students studying in tourism faculties. In this study, intercultural sensitivity of 530 students studying in tourism faculties in Balıkesir and Çanakkale were investigated. For this study the intercultural sensitivity is formed four dimensions: "respect for cultural differences", "interaction confidence", "interaction enjoyment" and "interaction engagement". In dimensions of cultural sensitivity, "respect for cultural differences" dimension has highest mean, whereas "interaction confidence" dimension has lowest mean.
\end{abstract}

Keywords: Intercultural Sensitivity, Çanakkale, Balıkesir, Faculty of Tourism.

Received: 31.03 .2020

Accepted: 02.07.2020

\section{Suggested Citation:}

Saatcl, G. and Türkmen, S. (2020). A Comparative Research on the Determination of Intercultural Sensitivity Levels of Tourism Students, Journal of Turkish Tourism Research, 4(3): 1958-1970.

(C) 2020 Türk Turizm Araştırmaları Dergisi. 


\section{Gíriş}

İnsanoğlu varoluşundan günümüze kadar, hayatının her alanında düşüncelerini başka insanlara aktarmak için iletişime ihtiyaç duymuştur. İletişim, çok eski çağlarda işaret dili ve değişik sesler çıkarılarak sağlanırken, artık jest ve mimikler, teknoloji ve en önemlisi de dil ile desteklenmektedir (Öztürk, 1999). Dil aynı zamanda kültürün oluşmasını sağlayan bir etkendir. Kültürün oluşumunu etkileyen faktörler birçok kişi tarafından tanımlanmış olmakla birlikte genel olarak varılan sonuç, din, dil, eğitim durumu, gelişmişlik seviyesi, tarihsel geçmiş ve kurumsal faktörler olarak belirlenmiştir. Kişinin içinde bulunduğu toplum, onun değer yargılarını, davranışlarını, normlarını ve olayları değerlendirme biçimlerini de değiştirmektedir. Farklı kültürlere mensup insanların davranışları, olayları değerlendirme ve anlama durumları, sahip oldukları normlar, kültürleri gibi etkenlerle farklılık gösterebilmektedir. Farklı kültüre sahip insanların etkileşimi sonucunda, çatışma ve iletişim bozuklukları olabileceği gibi problemlerin çözümü, yaratıcılık ve yenilikçilik konularında gelişim de sağlanabilmektedir (Yeşil, 2013).

Genel olarak kültürlerarası iletişim, farklı kültürlere mensup kişiler arasında, birbirini anlayabilme amacı kapsamında gerçekleşen iletişim ve etkileşim sürecini ifade etmektedir. Dünyada son gelinen noktada, teknolojinin gelişmesi ile birlikte hiçbir ülke diğerleriyle bağlantısını keserek yaşamını sürdürememektedir. İletişim sistemlerinin gelişmesi, nüfusun günden güne artması, turizm faaliyetlerinin fazlalaşması, dünya ekonomisindeki değişiklikler, gerçekleşebilecek belli nedenlere bağlı göç hareketleri gibi birçok faktör, kültürlerarası iletişimi zorunlu kılmaktadır. Bu durum kültürlerarası iletişimin tamamlayıcısı niteliğinde olan kültürlerarası duyarlılığın önemini de arttırmıştır. Araştırmanın temelini oluşturan kültürlerarası duyarlılık kavramı, kültürel farklılıkların anlaşılmasında kültürlerarası iletişim için gerekli davranış biçiminin oluşmasını destekleyen, olumlu duyguyu geliştirebilme yeteneği olarak tanımlanabilmektedir. Buna göre, kültürlerarası duyarlılık sahibi bireyler, farklılıkları anlayıp kabul etmeye eğilimlidirler. Bu kabul ediş, kültürlerarası etkileşimin olumlu duygu ve sonuçlarını doğurmaktadır. Söz konusu olumlu duygular; önyargısız, yargılamayan, anlayıp tanımaya yönelik ve saygıyla yaklaşan duygular olarak ifade edilmektedir (Bekiroğlu ve Balcı, 2014).

\section{İLGILII YAZIN}

Kültür kavramı, Latince bir terim olan "cultura" kelimesinden türetilerek (Yeşil, 2013), genel olarak, bir insan topluluğu tarafından öğrenilen ve yaygınlaştırılarak, gelecek nesillere aktarılan örf, adet, inanç, gelenek, görenek ve değerlerin tamamı olarak tanımlanmaktadır (Bulduk, Usta ve Dinçer, 2017). Bireylerin ve toplumun varoluş biçimlerini, yaşam tarzlarını, iletişimlerini, etkileşimlerini, düşüncelerini bir arada anlamak ve yaşamak olarak da ifade edilen kültürün (Demir, 2011), yayılmasını ve oluşumunu sağlayan iletişim ise, bireylerin birbirini anlaması, duygularını paylaşması, ihtiyaç duyduğu şeyleri ifade etmesi için kullandığı yoldur. Bireyler iletişim yoluyla yaşadığı toplumdaki örf, adet, gelenek ve kültürü etkili bir şekilde yayabilmektedir. İletişime geçen bireyler, anlam yükleme ve anlam çıkartmayı kendi anlayış biçimlerine göre yorumlayabilmektedirler. Aynı konunun anlamı bireyden bireye farklılık gösterebilmektedir. Bu durum, her bireyin farklı kültüre sahip olması ve olaylara kendi açısından bakması ile de ifade edilebilmektedir (Üstün, 2005). Örneğin Yağbasan (2010) çalışmasında, Türk ve Yunan toplumlarının arasında çekişme olmasına rağmen dillerinde birçok ortak sözcük bulunmasından bahsetmiştir. Bu iki toplumun dilleri arasındaki ortak sözcüklerin olmasını kültürlerarası iletişim açısından inceleyerek, her iki dilin belli kurallar 
doğrultusunda oluştuğu fakat iki dil arasında gözden kaçırılamayacak kadar benzerliklerin olduğunu saptamıştır.

Kültürün geçmişi incelendiğinde her kültürün diğeri ile daima etkileşim içinde olduğu görülmektedir. Bireyler, kendi bakış açısı ile tarafsız bir şekilde ifade ettiğini sandığ tutumlarına bile, yaşadığı toplumun kültürel bağlantılarını ele alarak anlam yüklemektedir. Algılanan durum benzer olduğu halde çıkarılan ifade farklılık gösterebilmekte ve sunulan ifadeye karşı belirlenecek yaklaşım kültürden kültüre değişebilmektedir. Birey farklı bir sistem içine girdiğinde kendi kültürünün davranışlarını sürdürdüğünü fakat bu davranışlarının farklı kültür olgularında bulunmadığını fark edecektir. Bu durum girdiği sistemin kültürel olgusundaki etkileşimi ifade etmektedir. Davranışlarındaki kültürel farklılıkları gören birey, kendisini söz konusu sisteme göre yönlendirmek isteyecek ancak bu zamanla sağlanacak veya aksi durumda farklılıklar hiç fark edilmeyecek ve adaptasyon sağlanamayacaktır. Farklı kültüre ait bir sisteme giren kişi, o sistemde kendinden beklenen davranışların ve bireyin toplumdaki olgusunun ne yönde olduğunu bilemeyebilecektir (Aliyev ve Öğülmüş, 2015).

Kültürlerarası iletişim ise, birbirinden ayrı kültürlerden bir araya gelen insanların birbirleriyle kurduğu iletişimi ifade etmektedir. Birey, bulunduğu ortamda farklı kültüre sahip bir insanla etkileşimde bulunarak, o kültüre ait özellikleri hayatına yansıtabilmektedir. Bu doğrultuda bireyin topluma karşı duruşu, davranış biçimi doğrudan ya da dolaylı olarak değişebilmektedir. Bireyler, genellikle hayata karşı tutumlarını ve davranışlarını toplumdan edindiği kültür birikimiyle yönlendirmektedir. Farklı kültürlere sahip insanlarla kurulan iletişimin devamlılığı ile kültürlerarası etkileşim sağlanabilmekte ve bu bağlamda kültürel farklılıkların birbiriyle harmanlanmasının temeli atılmaktadır (Bozkaya, 2010). Benzer olarak Özdemir (2011) de, farklı kültürlere sahip insanların birbirine karşı önyargısız, hoşgörüye dayalı ve anlayış göstererek iletişim içinde olmalarının, insanların barış ve mutluluk içinde geçinmelerini sağlayacağından, aksi durumda ön yargıların, ayrımcılığın olduğu yerde barış ortamının oluşturulmasının imkânsız olduğundan söz etmiştir. Aynı zamanda kültürel bilinçlenmenin insani duyguları geliştirdiğini de ifade etmiştir. Bununla birlikte Düztaş (2012) da farklı kültürel beklentilerin, kültürel çatışmaya, dolayısıyla anlaşmazlıklara yol açabileceğini vurgulamıştır.

Kültürlerarası duyarlılık da kültürlerarası iletişimin bir parçasıdır. Kültürlerarası duyarlılık, insanların kültürel farklarının anlaşılmasında ve tanımlanmasında etkili bir davranış şekli, aynı zamanda pozitif duyguyu ilerletebilme yeteneği olarak ifade edilmektedir. Kültürlerarası duyarlılık, farklı kültürdeki insanların davranışlarına, düşüncelerine, hissettiklerine, yükledikleri anlamlara, verdikleri değerlere saygı göstermek ve duyarlı davranmaktır. Kültürlerarası duyarlılık sadece farklılıkların farkında olmak değil aynı zamanda diğer kültürlerden olan kişilerle de etkili iletişim kurmayı kapsamaktadır. Bir başka ifadeyle, farklı bir kültürün izini taşıyan kişilerde ya da ortamlarda farklılık olarak görülen şeyleri kabul etmeye ve öğrenmeye istekli olabilme gibi etkileri barındıran bir durum olarak tanımlanmaktadır. Bununla birlikte kültürlerarası duyarlılık, bireyleri farklı kültürel ortamlarda başarılı bir yaşam ve çalışma hayatına hazırlayan, farklı kültürden insanlara ilişkin fikirlerini analiz etmede onlara yardımcı olan ve farklı kültürel ortamlara ilişkin tecrübe elde etmesini sağlayan kültürlerarası yeterlilik olarak da değerlendirilmektedir. Yine kültürlerarası duyarlılık, kültürel farklılıklar ile baş etmek için bireyin sahip olduğu psikolojik gücünün derecesini gösterir ve kültürlerarası iletişim yeterliliği kazanılmasının ön koşulu olarak değerlendirilmektedir (Chen ve Starosta, 2000; Zhu, 2011; Bekiroğlu ve Balc1, 2014; Bulduk, Usta ve Dinçer, 2017; Abaslı, 2018; Kürtüncü vd., 2018; Öğüt ve Olkun, 2018). Örneğin Demir ve Demir (2009)'in kültürlerarası iletişim ve etkileşim bağlamında, eğitimlerinin bir kısmını yurtdışında devam ettiren öğrenci değişim programlarında bulunan öğrencilerin deneyimlerini 
ve evrensel kültürün oluşturulması açısından katkılarını incelediği çalışmada, söz konusu programlara katılan öğretmen adaylarının önyargılarını yendikleri, farklı kültürleri tanıdıkları ve kendi kültürlerinin farkına vardıkları saptanmıştır. Ayrıca mesleki özgüvenlerinin geliştiği ve yabancı dillerini de ilerlettikleri sonucuna ulaşmışlardır.

Kültürlerarası duyarlılık bir kişinin kültürlerarası iletişimde uygun ve etkili bir davranışı teşvik eden kültürel farklılıkları anlama ve takdir etme yönünde olumlu bir duygu geliştirme yeteneği olarak kavramlaşabilmektedir. Bu tanım, kültürlerarası duyarlılı̆̆ın dinamik bir kavram olduğunu göstermektedir. Bu durum ise kültürlerarası duyarlılığa sahip kişilerin, kültürlerarasındaki farklılıkları anlamaları, takdir etmeleri ve kabul etmeleri için kendilerini motive etme ve kültürlerarası etkileşimlerden olumlu sonuçlar üretme arzusuna sahip olduklarını ortaya koymaktadır (Öğüt ve Olkun, 2018). Diğer bir deyişle kültürlerarası duyarlılık, kültürel farklılıkları anlamaya ve keşfetmeye yönelik pozitif duyguların geliştirilebilmesi olarak tanımlanmakta ve bu doğrultuda kültürlerarası yeterliğin desteklenmesi için bireylerin sahip olmaları gereken birtakım özelliklere dikkat çekmektedir. Bu özellikler; özsaygı, özdenetim, açı fikirlilik, empati, etkileşimli ilişki ve önyargılı ya da peşin hükümlü olmama şeklinde sıralanabilmektedir (Mercan, 2016). Kültürlerarası duyarlılık, kültürlerarası iletişim becerisinin bir parçasıdır ve temel unsurlarından birisi empatidir. Empati, bir kişinin kendini karşısındaki kişinin yerine koyarak, olaylara onun bakış açısı ile bakması ve o kişinin duygu ve düşüncelerini doğru olarak anlaması ve bu durumu iletmesi sürecidir (Cetişli Egelioğlu vd., 2016). Bu nedenle toplumumuzda zaten var olan çok kültürlülük gerçeği, kültürel farklılıkları anlama ve kültürlerarası ilişkiler konusunda mesleki eğitim verenleri de etraflıca düşünmeye yöneltmektedir. Gün geçtikçe genişleyen farklı kültürel özelliklere sahip bireyler ile birlikte yaşayabilme, çalışabilme beceri ve bilincine sahip olmanın önemi daha da çok ön plana çıkmaktadır (Bulduk, Usta ve Dinçer, 2017).

\section{YÖNTEM}

$\mathrm{Bu}$ çalışmanın amacı turizm eğitimi alan öğrencilerin kültürlerarası duyarlılık düzeylerinin tespit edilmesidir. Bu kapsamda bu araştırmada; Chen ve Starosta (2000) tarafından geliştirilen 24 maddelik 5'li Likert tipi “Kültürlerarası Duyarlılık Ölçeği"nden faydalanılmıştır. Araştırmada kullanılan ölçeğin 2011 yılında Bulduk, Tosun ve Ardıç (2011) tarafından Türkçe'ye uyarlanarak geçerlilik ve güvenirlik çalışması yapılmış, Cronbach Alpha katsayısı .72 (yeterli) olarak hesaplanmıştır. Bu çalışmada da Bulduk vd. (2011) uyarladıkları ölçekten faydalanılmıştır. Bireylerin kültürlerarası duyarlılık düzeylerini tespit etmek amacıyla geliştirilen ölçeğin orijinal formu, beşli Likert biçiminde düzenlenmiş, 24 tutum ifadesi ve 5 alt boyuttan oluşmaktadır. Boyutlar, kültürlerarası etkileşime katılım, kültürel farklılıklara saygı, kültürlerarası etkileşimde kendine güvenme, kültürlerarası etkileşimden hoşlanma ve kültürlerarası etkileşim sorumluluğu olarak isimlendirilmiştir. 24 maddeden oluşan kültürlerarası duyarlılık ölçeği, beş maddenin faktör yükünün düşük olması (0,50'den az) ve üç maddenin de binişik madde olması sebebiyle faktör analizinden çıkarılmıştır. Faktör analizi sonucunda, dört faktör ortaya çıkmıştır. Araştırma verilerinin analizlerinde frekans ve yüzde dağılımları, aritmetik ortalama ve standart sapma değerleri, açıklayıcı faktör analizi ve farklılık testleri uygulanmıştır.

Araştırma evrenini Balıkesir ve Çanakkale'deki turizm fakültelerinde eğitim gören öğrenciler oluşturmaktadır. 2019-2020 eğitim-öğretim yılında, Balıkesir Üniversitesi Turizm Fakültesi'nde (BAUN TF), "Turizm İşletmeciliği", "Turizm Rehberliği", "Gastronomi ve Mutfak Sanatları" ve "Rekreasyon Yönetimi" bölümlerinde olmak üzere toplam 1388 öğrenci aktif olarak eğitimöğretime devam etmektedir. Çanakkale Onsekiz Mart Üniversitesi Turizm Fakültesi'nde 
(ÇOMÜ TF) ise "Konaklama İşletmeciliği", "Seyahat İşletmeciliği ve Turizm Rehberliği" ile "Gastronomi ve Mutfak Sanatları" bölümlerinde olmak üzere toplam 1040 öğrenci aktif öğrenci konumundadır. 10.12.2019-31.12.2019 tarihleri arasında kolayda örnekleme yöntemi ile derslerden önce öğrencilere toplam 650 anket formu dağıtılmıştır. BAUN TF'den 275 ve ÇOMÜ $\mathrm{TF}^{\prime}$ den 255 analize uygun anket formu elde edilmiştir. Dolayısıyla araştırmanın örneklemini toplam 530 öğrenci oluşturmuştur.

\section{BULGULAR}

Aşağıda yer alan Tablo 1'de iki farklı üniversitede eğitim gören gruba ait demografik özellikler yer almaktadır. Öğrencilerin yaklaşık \%50'si erkek ve \%94'ü de 19-25 yaş grubu arasında yer almaktadır. Öğrenim gördükleri sınıflara bakıldığında yaklaşık \%35 ile en kalabalık grup 3. sınıf olurken; 1. ve 2. sınıflarda eğitim gören öğrenci gruplarının yüzdesel dağılımları yaklaşık \%26'şar olarak ortaya çıkmıştır. Turizm fakültelerinin altında yer alan bölümler farklı olduğu için toplam üzerinden değerlendirme yapılmamıştır. Balıkesir Üniversitesi Turizm Fakültesi öğrencilerinin yaklaşık \%40' 1 Turizm İşletmeciliği ve \%34'ü de Gastronomi ve Mutfak Sanatları Bölümü'nde öğrenim görmektedirler. Çanakkale Onsekiz Mart Üniversitesi Turizm Fakültesi öğrencilerinin yaklaşık \%35'i Konaklama İşletmeciliği, \%34'ü Gastronomi ve Mutfak Sanatları Bölümü'nde öğrenim görmektedirler.

Tablo 1. Araştırma Grubunun Demografik Özellikleri

\begin{tabular}{|c|c|c|c|c|c|c|c|}
\hline \multicolumn{3}{|c|}{ BAUN Turizm Fakültesi } & \multicolumn{3}{|c|}{ ÇOMÜ Turizm Fakültesi } & \multicolumn{2}{|c|}{ Genel Toplam } \\
\hline Değişken & $\mathbf{n}$ & $\%$ & Değişken & $\mathbf{n}$ & $\%$ & $n$ & $\%$ \\
\hline \multicolumn{3}{|c|}{ Cinsiyet } & \multicolumn{3}{|l|}{ Cinsiyet } & \multicolumn{2}{|c|}{ Cinsiyet } \\
\hline Kadın & 121 & 44,0 & Kadın & 142 & 55,7 & 263 & 49,7 \\
\hline Erkek & 154 & 56,0 & Erkek & 113 & 44,3 & 267 & 50,3 \\
\hline Toplam & 275 & 100 & Toplam & 255 & 100 & 530 & 100 \\
\hline \multicolumn{3}{|c|}{ Yaş } & \multicolumn{3}{|l|}{ Yaş } & \multicolumn{2}{|c|}{ Yaş } \\
\hline 18 yaş ve altı & 12 & 4,4 & 18 yaş ve altı & 7 & 2,7 & 19 & 3,58 \\
\hline $19-25$ yaş arası & 254 & 92,4 & $19-25$ yaş arası & 242 & 94,9 & 496 & 93,58 \\
\hline 26 yaş ve üzeri & 9 & 3,2 & 26 yaş ve üzeri & 6 & 2,4 & 15 & 2,83 \\
\hline Toplam & 275 & 100 & Toplam & 255 & 100 & 530 & 100 \\
\hline \multicolumn{3}{|c|}{ Sinif } & \multicolumn{3}{|l|}{ Sinif } & \multicolumn{2}{|c|}{ Sinıf } \\
\hline 1. sinif & 72 & 26,2 & 1. sinif & 66 & 25,9 & 138 & 26,04 \\
\hline 2. sinif & 86 & 31,3 & 2. sinif & 50 & 19,6 & 136 & 25,66 \\
\hline 3. sinif & 91 & 33,1 & 3. sinif & 96 & 37,6 & 187 & 35,28 \\
\hline 4. sinif & 26 & 9,4 & 4. $\sin i f$ & 43 & 16,9 & 69 & 13,02 \\
\hline Toplam & 275 & 100 & Toplam & 255 & 100 & 530 & 100 \\
\hline \multicolumn{3}{|c|}{ Bölüm } & \multicolumn{3}{|l|}{ Bölüm } & \multicolumn{2}{|c|}{ Bölüm } \\
\hline Turizm İşletmeciliği & 112 & 40,7 & Konaklama İşletmeciliği & 89 & 34,9 & \multirow{4}{*}{\multicolumn{2}{|c|}{ * }} \\
\hline Turizm Rehberliği & 47 & 17,1 & Seyahat İş. ve Turizm Reh. & 79 & 31,0 & & \\
\hline $\begin{array}{l}\text { Gastronomi ve } \\
\text { Mutfak Sanatları }\end{array}$ & 92 & 33,5 & \multirow[t]{2}{*}{$\begin{array}{lll}\text { Gastronomi } & \text { ve } & \text { Mutfak } \\
\text { Sanatları } & & \end{array}$} & 87 & 34,1 & & \\
\hline $\begin{array}{l}\text { Rekreasyon } \\
\text { Yönetimi }\end{array}$ & 24 & 8,7 & & & & & \\
\hline Toplam & 275 & 100 & Toplam & 255 & 100 & 530 & 100 \\
\hline
\end{tabular}


Tablo 2. Kültürlerarası Duyarlılık Ölçeği'ndeki İfadelere Ait Aritmetik Ortalama ve Standart Sapma Değerleri

\begin{tabular}{|c|c|c|c|c|c|c|c|}
\hline \multirow{2}{*}{\multicolumn{2}{|c|}{ İfadeler }} & \multicolumn{2}{|c|}{ BAUN TF } & \multicolumn{2}{|c|}{ ÇOMÜ TF } & \multicolumn{2}{|c|}{ Toplam } \\
\hline & & \multirow{2}{*}{$\begin{array}{c}\bar{x} \\
4,11\end{array}$} & \multirow{2}{*}{$\begin{array}{c}\text { s.s. } \\
, 982\end{array}$} & \multirow{2}{*}{$\frac{\bar{x}}{4,49}$} & \multirow{2}{*}{$\begin{array}{c}\text { s.s. } \\
\text {,792 }\end{array}$} & \multirow{2}{*}{$\frac{\bar{x}}{4,29}$} & \multirow{2}{*}{$\begin{array}{l}\text { s.s. } \\
914\end{array}$} \\
\hline D1 & $\begin{array}{lll}\begin{array}{l}\text { Farklı kültürlerden } \\
\text { girmekten hoşlanırım. }\end{array} & & \text { insanlarla } \\
\end{array}$ & & & & & & \\
\hline D2 & Bence diğer kültürlerin insanları dar görüşlüdür. ${ }^{\circledR}$ & 4,07 & 1,001 & 4,08 & 1,079 & 4,07 & 1,038 \\
\hline D3 & $\begin{array}{l}\text { Farklı kültürlerden insanlarla etkileşim kurma } \\
\text { konusunda kendimden oldukça eminim. }\end{array}$ & 3,84 & ,885 & 3,93 & ,934 & 3,88 & ,909 \\
\hline D4 & $\begin{array}{l}\begin{array}{l}\text { Farklı kültürlerden } \\
\text { konuşmakta zorlanırım. }{ }^{\circledR}\end{array} \\
\end{array}$ & 3,47 & 1,057 & 3,58 & 1,101 & 3,52 & 1,079 \\
\hline D5 & $\begin{array}{l}\text { Farklı kültürlerden insanlarla etkileşime girerken } \\
\text { ne söyleyeceğimi her zaman bilirim. }\end{array}$ & 3,44 & ,992 & 3,56 & ,944 & 3,50 & ,970 \\
\hline D6 & $\begin{array}{l}\text { Farklı kültürlerden insanlarla etkileşime girerken } \\
\text { istediğim kadar sosyal olabilirim. }\end{array}$ & 3,66 & ,931 & 3,81 & 891 & 3,73 & ,914 \\
\hline D7 & $\begin{array}{l}\text { Farklı kültürlerden insanlarla vakit geçirmekten } \\
\text { hoşlanmıyorum. }{ }^{\circledR}\end{array}$ & 4,03 & 1,150 & 3,89 & 1,316 & 3,96 & 1,233 \\
\hline D8 & $\begin{array}{l}\text { Farklı kültürlerden insanların değerlerine sayg1 } \\
\text { duyarım. }\end{array}$ & 4,43 & 786 & 4,47 & ,864 & 4,45 & ,824 \\
\hline D9 & $\begin{array}{l}\text { Farklı kültürlerden insanlarla etkileşim kurarken } \\
\text { kolaylıkla gerilirim. }{ }^{\circledR}\end{array}$ & 3,43 & 1,116 & 3,52 & 1,189 & 3,47 & 1,152 \\
\hline D10 & $\begin{array}{l}\text { Farklı kültürlerden insanlarla etkileşim kurarken } \\
\text { kendime güvenirim. }\end{array}$ & 3,84 & ,979 & 3,99 & ,924 & 3,91 & ,955 \\
\hline D11 & $\begin{array}{l}\text { Kültürleri farklı akranlarım hakkında bir izlenim } \\
\text { oluşturmadan önce beklerim. }\end{array}$ & 3,76 & ,923 & 3,76 & ,929 & 3,76 & ,925 \\
\hline D12 & $\begin{array}{l}\text { Farklı kültürlerden insanlarla birlikteyken } \\
\text { genellikle cesaretim kırılır. }{ }^{\circledR}\end{array}$ & 3,86 & 1,081 & 3,96 & 1,064 & 3,91 & 1,073 \\
\hline D13 & $\begin{array}{llll}\begin{array}{l}\text { Farklı kültürlerden } \\
\text { görüşlüyümdür. }\end{array} & \text { insanlara } & \text { karşı açık } \\
\end{array}$ & 4,17 & ,753 & 4,30 & ,841 & 4,23 & 798 \\
\hline D14 & $\begin{array}{l}\text { Farklı kültürlerden insanlarla etkileşim kurarken } \\
\text { çok iyi gözlem yaparım. }\end{array}$ & 3,72 & ,910 & 3,95 & ,920 & 3,83 & ,921 \\
\hline D15 & $\begin{array}{l}\text { Farklı kültürlerden insanlarla etkileşim kurarken } \\
\text { genellikle kendimi işe yaramaz hissediyorum. }{ }^{\circledR}\end{array}$ & 4,30 & 1,008 & 4,28 & 1,034 & 4,29 & 1,020 \\
\hline D16 & $\begin{array}{l}\text { Farklı kültürlerden insanların davranışlarına saygı } \\
\text { duyarım. }\end{array}$ & 4,35 & ,766 & 4,40 & ,881 & 4,38 & 823 \\
\hline D17 & $\begin{array}{l}\text { Farklı kültürlerden insanlarla etkileşim kurarken } \\
\text { mümkün olduğunca çok bilgi edinmeye çalışırım. }\end{array}$ & 3,94 & ,914 & 4,29 & ,828 & 4,11 & 890 \\
\hline D18 & $\begin{array}{l}\text { Farklı kültürlerden insanların görüşlerini kabul } \\
\text { etmem. } ®\end{array}$ & 4,29 & ,927 & 4,40 & 899 & 4,35 & ,914 \\
\hline D19 & $\begin{array}{l}\text { Farklı kültürlerden insanlarla etkileşim kurarken } \\
\text { ince anlamlarına duyarlı davranırım. }\end{array}$ & 3,94 & ,989 & 4,17 & ,988 & 4,05 & ,994 \\
\hline D20 & $\begin{array}{l}\text { Benim kültürümün diğer kültürlerden daha iyi } \\
\text { olduğunu düşünüyorum. }{ }^{\circledR}\end{array}$ & 3,18 & 1,303 & 3,16 & 1,304 & 3,17 & 1,302 \\
\hline D21 & $\begin{array}{l}\text { Etkileşimimiz sırasında kültürel açıdan farklı } \\
\text { insanlara genellikle olumlu tepkiler veriyorum. }\end{array}$ & 3,97 & ,853 & 4,10 & ,899 & 4,03 & 877 \\
\hline D22 & $\begin{array}{l}\text { Kültürel açıdan farklı insanlarla uğraşmak } \\
\text { zorunda kalacağım durumlardan kaçınırım. }{ }^{\circledR}\end{array}$ & 3,79 & 1,057 & 3,99 & 1,095 & 3,89 & 1,079 \\
\hline D23 & $\begin{array}{l}\text { Kültürel açıdan farklı olan insanlara, sözle veya } \\
\text { hareketlerimle onu anladığımı gösteririm. }\end{array}$ & 4,04 & ,811 & 4,30 & 783 & 4,16 & 808 \\
\hline D24 & $\begin{array}{l}\text { Kültürel açıdan farklı insanlar ile aramdaki } \\
\text { farklılıklardan zevk alırım. }\end{array}$ & 3,44 & 1,235 & 4,01 & 1,120 & 3,72 & 1,214 \\
\hline & Genel Ortalama & 3,88 & ,975 & 4,02 & ,984 & 3,94 & ,984 \\
\hline
\end{tabular}


Tablo 2'de öğrencilerin kültürlerarası duyarlılık ölçeğinde yer alan ifadelere ilişkin verdikleri yanıtların aritmetik ortalamaları ve standart sapma değerleri yer almaktadır. Çanakkale'de öğrenim gören öğrencilerin kültürel duyarlılık düzeyleri $(X=4,02)$, Balıkesir'de öğrenim gören öğrencilerin kültürel duyarlılık düzeylerine $(X=3,88)$ göre nispeten daha yüksek düzeyde ortaya çıkmıştır. Bütün öğrenciler ele alındığında kültürel duyarlılıkla ilgili yanıtlara katılım oranı 3,94 düzeyinde ortaya çıkmıştır.

Öğrencilerin kültürlerarası duyarlılık düzeylerini ölçen ifadelere katılım seviyeleri değerlendirildiğinde, BAUN TF öğrencilerinin en yüksek katılım gösterdiği ifadeler "farklı kültürlerdeki insanların değerlerine $(X=4,43)$ ve davranışlarına $(X=4,35)$ saygı duyma" olmuştur. ÇOMÜ TF öğrencilerinin en yüksek katılım gösterdiği ifadeler ise "farklı kültürlerden insanlarla etkileşime girmekten hoşlanma" $(X=4,49)$ ve "farklı kültürlerdeki insanların davranışlarına $\left(X^{=}=4,47\right)$ saygı duyma" ifadeleri olmuştur. En az katılım gösterilen ifadeler değerlendirildiğinde ise her iki şehirdeki öğrenciler için aynı ifadeler olmuştur. Bu ifadeler "farklı kültürden insanlarla iletişim kurarken kolaylıkla gerilme" (®Balıkesir $X=3,43$; Çanakkale $X=3,52)$ ve "kendi kültürünün diğer kültürlerden daha iyi olması" (®Balıkesir $X=3,18$; Çanakkale $X=3,16$ ) ile ilgili olan ifadelerdir.

Kültürlerarası duyarlılık ölçeğine açıklayıcı faktör analizi (AFA) yapılmadan önce ölçeğin güvenilirliğine ve normal dağglımına bakılmıştır. Ölçek için Cronbach'ın alfa güvenirlik katsayısı $(\alpha)$ 0,867 düzeyinde ortaya çıkmış ve normal dağılım çarpıklık-basıklık değerlerine göre değerlendirilmiştir. Ölçekte yer alan ifadelerin çarpıklık-basıklık $\pm 1,5$ değerine göre değerlendirilmiş (Tabachnick ve Fidell, 2013) ve ölçeğin normal dağılım gösterdiği ortaya çıkmıştır.

Aşağıdaki Tablo 3'te kültürlerarası duyarlılık ölçeğine ait Kaiser Mayer Olkin (KMO) ve Bartlett'in küresellik testi ile açıklayıcı faktör analizine ilişkin sonuçlar yer almaktadır. KMO değerinin 0,859 olduğu ve Bartlett'in küresellik testine göre yaklaşık ki-kare $(\chi 2)$ değerinin 3006,838 ve anlamlılık düzeyinin $p<0,001$ olduğu görülmektedir. Bu sonuçlar ölçeğin açılayıcı faktör analizine (AFA) uygun olduğunu göstermektedir.

Kültürlerarası duyarlılık ölçeği 24 maddeden oluşmakta, beş maddenin faktör yükünün düşük olması (0,50'den az) ve üç maddenin de binişik madde olması sebebiyle faktör analizinden çıkarılmıştır. Faktör analizi sonucunda, dört faktör ortaya çıkmış ve bu dört faktörün toplam açıklanan varyansı \%61,79 düzeyinde ortaya çıkmıştır.

Tablo 3'e göre birinci faktör; ölçeği en yüksek düzeyde $(\% 17,10)$ açılayan faktör olmuştur. Dört maddenin yer aldığı bu faktörün 3 maddesi (D16, D8 ve D18) orijinal ölçekte "kültürel farklılıklara sayg1" boyutunda yer aldığı için bu faktöre "kültürel farklılıklara saygı" denilmiştir. Ayrıca katılımcıların en yüksek düzeyde $(X=4,31)$ katılım gösterdiği boyut olmuştur. İkinci boyut ölçeğin \%15,99'unu açıklamakta ve boyutta yer alan dört madde de orijinal ölçekte "etkileşimde kendine güvenme" boyutunda yer aldığı için bu boyut da aynı isimle ifade edilmiştir. Etkileşimde kendine güvenme boyutu, dört boyut içerisinde katılımın en düşük $(X=3,76)$ olduğu boyut olmuştur. Üçüncü boyut dört maddeden oluşurken ölçeği \%15,54 düzeyinde açıklamakta ve bu boyutta yer alan üç madde (D12, D15 ve D9) orijinal ölçekte "etkileşimden hoşlanma" boyutunda yer aldığı için aynı isimle ifade edilmiştir. Etkileşimden hoşlanma boyutuna katılım düzeyi 3,80 olarak tespit edilmiştir. Dördüncü ve son boyut da dört ifadeden oluşmuş ve bu ifadelerden üçü (D22, D23 ve D24) orijinal ölçekte "etkileşim sorumluluğu" boyutunda yer aldığı için yine aynı şekilde isimlendirilmiştir. Etkileşim sorumluluğu boyutuna da katılım düzeyi 3,97 düzeyinde tespit edilmiştir. 
Tablo 3. Kültürlerarası Duyarlılık Ölçeğinin Açıklayıcı Faktör Analizi Sonuçları

\begin{tabular}{|c|c|c|c|c|c|c|}
\hline \multicolumn{2}{|r|}{ Maddeler } & \multirow{2}{*}{$\begin{array}{l}\text { F1 } \\
862 \\
\end{array}$} & \multirow[t]{2}{*}{ F2 } & \multirow[t]{2}{*}{ F3 } & \multirow[t]{2}{*}{ F4 } & \multirow{2}{*}{$\begin{array}{c}\text { OVY } \\
, 778 \\
\end{array}$} \\
\hline D16 & Farklı kültürlerden insanların davranışlarına saygı duyarım. & & & & & \\
\hline D8 & Farklı kültürlerden insanların değerlerine saygı duyarım. &, 749 & & & & 604 \\
\hline D18 & Farklı kültürlerden insanların görüşlerini kabul etmem. ® &, 728 & & & & 622 \\
\hline D21 & $\begin{array}{l}\text { Etkileşimimiz sırasında kültürel açıdan farklı insanlara } \\
\text { genellikle olumlu tepkiler veriyorum. }\end{array}$ & 655 & & & &, 502 \\
\hline D5 & $\begin{array}{lcccc}\begin{array}{l}\text { Farklı kültürlerden } \\
\text { söyleyeceğimi her zaman bilirim. }\end{array} & \text { etkileşime } & \text { girerken } & \text { ne } \\
\end{array}$ & & 818 & & & 693 \\
\hline D6 & $\begin{array}{l}\text { Farklı kültürlerden insanlarla etkileşime girerken istediğim } \\
\text { kadar sosyal olabilirim. }\end{array}$ & &, 812 & & & ,671 \\
\hline D3 & $\begin{array}{l}\text { Farklı kültürlerden insanlarla etkileşim kurma konusunda } \\
\text { kendimden oldukça eminim. }\end{array}$ & & ,727 & & & ,613 \\
\hline D10 & $\begin{array}{l}\text { Farklı kültürlerden insanlarla etkileşim kurarken kendime } \\
\text { güvenirim. }\end{array}$ & & ,619 & & & ,642 \\
\hline D12 & $\begin{array}{l}\text { Farklı kültürlerden insanlarla birlikteyken genellikle cesaretim } \\
\text { kırılır. }{ }^{\circledR}\end{array}$ & & & ,777 & & ,697 \\
\hline D15 & $\begin{array}{l}\text { Farklı kültürlerden insanlarla etkileşim kurarken genellikle } \\
\text { kendimi işe yaramaz hissediyorum. }{ }^{\circledR}\end{array}$ & & & ,747 & & ,642 \\
\hline D9 & $\begin{array}{l}\text { Farklı kültürlerden insanlarla etkileşim kurarken kolaylıkla } \\
\text { gerilirim. }{ }^{\circledR}\end{array}$ & & & 680 & &, 550 \\
\hline D4 & Farklı kültürlerden insanların önünde konuşmakta zorlanırım. ${ }^{\circledR}$ & & & 611 & & ,528 \\
\hline D23 & $\begin{array}{l}\text { Kültürel açıdan farklı olan insanlara, sözle veya hareketlerimle } \\
\text { onu anladığımı gösteririm. }\end{array}$ & & & & ,746 & ,633 \\
\hline D24 & $\begin{array}{l}\text { Kültürel açıdan farklı insanlar ile aramdaki farklılıklardan zevk } \\
\text { alırım. }\end{array}$ & & & & ,740 &, 588 \\
\hline D17 & $\begin{array}{l}\text { Farklı kültürlerden insanlarla etkileşim kurarken mümkün } \\
\text { olduğunca çok bilgi edinmeye çalışırım. }\end{array}$ & & & & 606 &, 544 \\
\hline D22 & $\begin{array}{l}\text { Kültürel açıdan farklı insanlarla uğraşmak zorunda kalacağım } \\
\text { durumlardan kaçınırım. @ }\end{array}$ & & & &, 573 &, 580 \\
\hline & Özdeğer & 2,737 & 2,559 & 2,486 & 2,105 & Genel \\
\hline & Açıklanan Varyans & 17,10 & 15,99 & 15,54 & 13,16 & 61,79 \\
\hline & Aritmetik Ortalama & 4,31 & 3,76 & 3,80 & 3,97 & 3,96 \\
\hline & Cronbach Alpha & 798 & 801 & 617 & 700 & ,854 \\
\hline & Kaiser Mayer Olkin Testi & 859 & & & & \\
\hline & Barlett'in Küresellik Testi & $\begin{array}{c}\chi^{2} \\
\text { df } \\
\text { sig. }\end{array}$ & & & & \\
\hline
\end{tabular}

Öğrencilerin eğitim aldıkları üniversite, cinsiyetleri ve okudukları sınıflara göre kültürlerarası duyarlılık düzeylerine göre farklılık olup olmadığını tespit etmek için yapılan farklılık testlerinin sonuçları aşağıdaki Tablo 4'te gösterilmiştir.

Tablo 4'te öğrencilerin cinsiyetlerine göre kültürlerarası duyarlılık düzeylerinin karşılaştırılması için yapılan t-testi sonucunda anlamlı bir fark tespit edilememiştir. Yine Yılmaz ve Göçen (2013)'in sınıf öğretmeni adaylarının kültürlerarası duyarlılık düzeylerini inceledikleri araştırmalarında da cinsiyet kültürlerarası duyarlılık açısından fark yaratmamıştır. Öğrencilerin eğitim aldıkları üniversiteye göre kültürlerarası duyarlılık düzeylerinde istatistiksel açıdan anlamlı bir fark $(\mathrm{t}=3,588 ; \mathrm{p}=.000<.001)$ tespit edilmiştir. Çanakkale Onsekiz Mart Üniversitesi'nde eğitim gören öğrenciler $(X=4,08)$, Balıkesir Üniversitesi'nde eğitim alan öğrencilere $(X=3,92)$ göre kültürlerarası duyarlılık düzeyleri daha yüksek seviyede ortaya çıkmıştır. Öğrencilerin bulundukları sınıflara göre yapılan karşılaştırmada da istatistiksel 
açıdan anlamlı ( $\mathrm{F}=4,596 ; \mathrm{p}=.003<.01)$ bir fark tespit edilmiştir. Birinci sınıf öğrencilerin ikinci ve üçüncü sınıf öğrencilerine göre kültürel duyarlılık düzeylerinin daha düşük olduğu tespit edilmiştir. Benzer olarak McMurray (2007; Akt. Rengi ve Polat, 2014), seyahat faktörünün kültürlerarası duyarlılığa etkisini incelemek amacıyla; uluslararası öğrenciler, yerel seyahat deneyimi olan öğrenciler ve yerel seyahat deneyimi olmayan öğrencilerin kültürlerarası duyarlılıklarını çeşitli değişkenler (cinsiyet, mezun olma durumu, yurt dışı çalışma programına katılım) açısından incelemiştir. Araştırma sonucunda; yerel seyahat deneyimi olan öğrencilerin ve yurt dışı çalışma programına katılım gösterenlerin kültürlerarası duyarlılığının daha yüksek olduğunu tespit etmiştir. Yine Demir ve Üstün'ün (2017) öğretmen adayları üzerinde yapmış olduğu araştırmada da; öğretmen adaylarının kültürlerarası duyarlılık düzeyleri arasında bölümlerine, mezun oldukları lise türlerine göre istatistiksel olarak anlamlı farklılık olduğunu tespit etmişlerdir. Farklılıklar incelendiğinde ise; İngilizce Öğretmeni adaylarının kültürlerarası duyarlılık düzeylerinin, Türk Dili ve Edebiyatı öğretmeni ve Sınıf öğretmenlerinden anlamlı bir şekilde yüksek olduğu sonucuna ulaşılmıştır.

Tablo 4. Farklılık Analizi Sonuçları

\begin{tabular}{|c|c|c|c|c|c|c|c|}
\hline & & \multicolumn{6}{|c|}{ Kültürlerarası Duyarlılık } \\
\hline Değişkenler & & $n$ & $\bar{X}$ & SS & $t / F$ & $p$ & Fark \\
\hline \multirow{2}{*}{ Cinsiyet } & Kadın & 263 & 4,03 & ,552 & \multirow{2}{*}{1,210} & \multirow{2}{*}{,227 } & \multirow{2}{*}{ Yok } \\
\hline & Erkek & 267 & 3,97 & 522 & & & \\
\hline \multirow{2}{*}{ Üniversite } & Çanakkale & 255 & 4,08 & 552 & \multirow{2}{*}{3,588} & \multirow{2}{*}{, $000^{* * *}$} & \multirow{2}{*}{0,17} \\
\hline & Balıkesir & 275 & 3,92 & ,513 & & & \\
\hline \multirow{4}{*}{ Sinif } & 1.Sinif & 138 & 3,90 & 1,176 & \multirow{4}{*}{4,596} & \multirow{4}{*}{, $003^{* *}$} & \multirow{4}{*}{$\begin{array}{l}1-2 \\
1-3\end{array}$} \\
\hline & 2.Sinif & 136 & 4,08 & 1,041 & & & \\
\hline & 3.Sinif & 187 & 4,05 & 1,173 & & & \\
\hline & 4.Sinif & 69 & 3,99 & 1,293 & & & \\
\hline \multicolumn{8}{|c|}{$\begin{array}{l}\text { "Farklar p<0,05 düzeyinde anlamlıdır. Farklılıkların analizi için } 2 \text { kategorili nominal değişkenlerde T-testi, } 2 \text { 'den fazla } \\
\text { kategoriye sahip nominal değişkenlerde ise Anova testine başvurulmuştur. Anova testinde varyansların eşitliği } \\
\text { varsayımı sağlandığı durumlarda Sheffe testi, sağlanmadığ durumlarda ise Tamhane testi kullanılmıştır. } \\
\qquad " p<0.05,{ }^{* *} p<0.01,{ }^{* * *} p<0.001\end{array}$} \\
\hline
\end{tabular}

\section{TARTIŞMA, SONUÇ ve ÖNERILER}

Turizmde istihdam edilen veya bir şekilde turizm faaliyetleri içerisinde yer alan kişilerin, sektörün paydaşlarının farklı uluslardan olması sebebiyle kültürlerarası duyarlılık düzeylerinin yüksek olması gerektiği düşünülmektedir. Duyarlılık; iletişimde başarıyı ve iletişimin de faaliyetlerin ve süreçlerin başarılı şekilde tamamlanmasına yardımcı olacaktır. Dolayısıyla küresel düzeyde en önemli konularından biri olan kültürlerarası duyarlılık, bu araştırmada Balıkesir Üniversitesi Turizm Fakültesi ile Çanakkale Onsekiz Mart Üniversitesi Turizm Fakültesi'nde öğrenim gören öğrenciler kapsamında ele alınmıştır. Bu çalışmada kültürlerarası duyarlılık seviyesi genel olarak 3,96 düzeyinde ve ölçek dört boyutta ortaya çıkmıştır. En yüksek katılım $(X=4,31)$ "kültürel farklılıklara saygı" boyutunda gerçekleşmiştir. Ancak "etkileşimde kendine güvenme" ve "etkileşimden hoşlanma" boyutlarına katılım düzeyleri sırasıyla 3,76 ve 3,80 düzeyinde ortaya çıkmış ve "kültürel farklılıklara saygı" boyutuna göre bu boyutlara katılım düzeylerinin düşük seviyelerde olduğu görülmüştür. Son boyut olan "etkileşim sorumluluğu" boyutu nispeten bu iki boyuta göre daha yüksek düzeyde $(X=3,97)$ ortaya çıkmıştır. Öğrencilerin farklı kültürlerle iletişim kurmalarında o kültürlere duydukları sayg1 ve iletişime ilişkin sorumluluklarının yüksek denilebilecek seviyede olduğu 
görülmektedir. Ancak turizm faaliyetleri içerisinde yer alacak olan bu öğrencilerin sektörün özellikleri açısından farklı kültürlerle etkileşim içerisinde olma konusunda kendilerine daha çok güvenmeleri gerekmektedir. Ayrıca öğrencilerin farklı kültürlerle etkileşimden hoşlanma düzeylerinin de daha ileriye taşınması gerekmektedir. Bu konuda öğrencilerin yabancı dil seviyelerinin yeterli olmaması veya yeterince farklı kültürleri tanımıyor olmaları farklı kültürlerle iletişim kurmada kendilerine güvenme sorunu oluşturabilir. Teknoloji ve sosyal medyanın yaygın kullanımı ile uluslararası iletişim ve etkileşim düzeyinin arttığı (Ahmadov, 2019) göz önünde bulundurulduğunda; öğrenciler kültürlerarası iletişim becerilerini geliştirebilmeleri için bu platformlardan destek alabilirler.

Ayrıca eğitim gördükleri süre içerisinde turizm fakültesi öğrencilerinin daha sık farklı kültürlerle buluşabilecekleri ortamlar sağlanmalıdır. Örneğin, Mrekajova (2018), Türkiye'deki yabancı uyruklu lisans, yüksek lisans ve doktora öğrencilerinin genel arkadaş bağlarını araştırırken, özellikle Türklerle olan iletişimlerini etkileyen olumlu ve olumsuz etkenleri incelediği çalışmasında öğrencilerin eğitim gördüğü üniversitelerde, konakladıkları kurumlarda yabancı ve Türk öğrenciler arasındaki kültürlerarası etkileşimin olumlu yönde pekiştirilmesi için programlar yapılması gerektiğini vurgulamıştır. Yaz aylarında yabancı turiste hizmet veren turizm işletmelerinde staj yapan veya çalışan öğrenciler bu açıdan avantajlı olabilirler ancak farklı kültürlerle temas edilebilecek ortamlar eğitim programlarında içerisinde de sağlanmalıdır. Mesleki yeterliliğin yanında iletişim becerilerinin geliştirilmesi kalite algısı üzerinde olumlu yönde bir etki yaratabilir. Özellikle de farklı kültürlerden insanlara hizmet verilen turizm sektöründeki aktörlerin iletişim becerilerinin gelişmesinde kültürel duyarlılığın çok önemli bir yerinin olduğu düşünülmektedir.

$\mathrm{Bu}$ bağlamda çalışmada elde edilen sonuçlardan hareketle; turizm öğrencileri kültürel farklılıklara sahip bireylerin tutum ve değerlerini anlamaya çalışmalıdırlar. Bu doğrultuda eğitim aldıkları kurumlarda müfredatları kapsamında ya da çeşitli seminer, toplantı vb. etkinlikler aracılığıyla kültürlerarası iletişim, etkileşim ve duyarlılık konularında bilinçlenmeleri sağlanmalıdır. Turizm öğrencileri kültürlerarası ölçekte empati kurabilmek adına öncelikle yetişmiş oldukları kültürü incelemeli ve öğrenmelidirler. Çünkü uluslararası platformda hizmet sağlayıcılar içerisinde aktif olarak rol alacak turizm öğrencileri bireylerin davranışlarının nedenlerinin altında yatan kültürel belirleyicileri bilmelidirler. Aynı zamanda öğrenciler birden fazla dil bilmeye ve öğrenmeye teşvik edilmeliler. Yine eğitim aldıkları kurumlarda değişim programlarıyla gelen diğer öğrenci gruplarının ana dilleri ile ilgili fikir sahibi olmaları da sağlanmalıdır.

Yapılan bu çalışmanın da birçok bilimsel araştırma gibi sınırlılıkları mevcuttur. Örneklem sayısı ve araştırma yapılan turizm fakültesi sayısı en önemli iki sınırlılığıdır. Daha sonraki yapılacak çalışmalarda özellikle farklı coğrafyalardaki turizm fakültelerindeki öğrenciler dahil edilerek yapıldığında daha farklı ve genellenebilir sonuçlara ulaşılabilir. Bu çalışmada sadece öğrencilerin kültürlerarası duyarlılık düzeyleri üzerinden analizler yapılmıştır. Sonraki çalışmalarda kalıp yargılar veya yabancı düşmanlığı gibi değişkenler eklenerek kültürel duyarlılı̆̆ın öncülleri araştırılabilir.

\section{KAYNAKÇA}

Abaslı, K. (2018). Kültürlerarası Duyarlılık ve Empati Arasındaki İlişkilerin Türk ve Uluslararası Öğrenci Görüşlerine Göre İncelenmesi, TÜBAV Bilim Dergisi, 11(2): 20-23.

Ahmadov, S. (2019). Kültürel Küreselleşme Aracı Olarak Sosyal Medyanın Tüketim Toplumuna Etkisi, Anadolu Akademi Sosyal Bilimler Dergisi, 1(1): 28-39. 
Aliyev, R. ve Öğülmüş, S. (2015). Türkiye'deki Yabancı Uyruklu Öğrencilerin Kültürlerarası Etkileşim Algısının İncelenmesi, 21. Yüzyılda Eğitim ve Toplum Eğitim Bilimleri ve Sosyal Araştırmalar Dergisi, 4(12): 49-71.

Bekiroğlu, O. ve Balcı, Ş. (2014). Kültürlerarası İletişim Duyarlılığının İzlerini Aramak: "İletişim Fakültesi Öğrencileri Örneğinde Bir Araştırma", Türkiyat Araştırmaları Dergisi, 35: 429-460.

Bozkaya, M. (2010). Kültürlerarası İletişim Kaygısı: Anadolu Üniversitesi Erasmus Öğrencileri Değişim Programı Örneği, İstanbul Üniversitesi Illetişim Fakültesi Dergisi, 1(39): 29-42.

Bulduk, S., Tosun, A. ve Ardıç, E. (2011). Türkçe Kültürlerarası Duyarlılık Ölçeğinin Hemşirelik Öğrencilerinde Ölçümsel Özellikleri, Türkiye Klinikleri Journal of Medical Ethics, 19(1): 25-31.

Bulduk, S., Usta, E. ve Dinçer, Y. (2017). Kültürlerarası Duyarlılık ve Etkileyen Faktörlerin Belirlenmesi: Bir Sağllk Hizmetleri Meslek Yüksekokulu Örneği, Düzce Üniversitesi Sağlık Bilimleri Enstitüsü Dergisi, 7(2): 73-77.

Cetişli Egelioğlu, N., Işık, G., Öztornacı Özgüven, B., Ardahan, E., Uran Özgürsoy, B., Top, E. ve Avdal Ünsal, E. (2016). Hemşirelik Öğrencilerinin Empati Düzeylerine Göre Kültürlerarası Duyarlılıkları, İzmir Kâtip Çelebi Üniversitesi Sağlık Bilimleri Fakültesi Dergisi, 1(1): 27-33.

Chen, G.M. and Starosta, W.J. (2000). The Development and Validation of The Intercultural Communication Sensitivity Scale, Human Communication, 3: 1-15.

Demir, A. ve Demir, S. (2009). Erasmus Programının Kültürlerarası Diyalog ve Etkileşim Açısından Değerlendirilmesi, Uluslararası Sosyal Araştırmalar Dergisi, 2(1): 95-105.

Demir, F. (2011). Bürokratik Kültür, Süleyman Demirel Üniversitesi İktisadi ve İdari Bilimler Fakültesi Dergisi, 2(12): 153-178.

Demir, S. ve Üstün, E. (2017). Öğretmen Adaylarının Kültürlerarası Duyarlılık ve Etnikmerkezcilik Düzeylerinin İncelenmesi, İnönü Üniversitesi Ĕ̆itim Fakültesi Dergisi, 18(3): 111.

Düztaş, D. (2012). Edward Morgan Forster'ın A Passage to India (Hindistan'a Bir Geçit) Adlı Romanında Kültürlerarası Etkileşim, Yayınlanmamış Yüksek Lisans Tezi, Fırat Üniversitesi, Elâzı̆̆.

Kürtüncü, M., Arslan, N., Çatalçam, S., Yapıcı, G. ve Hırçın, G. (2018). Yataklı Tedavi Kurumlarında Çalışan Hemşirelerin Kültürlerarası Duyarlılıkları ile Sosyo-Demografik Özellikleri ve Empati Düzeyleri Arasındaki İlişkisi, Hemşirelikte Araştırma Geliştirme Dergisi, 20(1): 44-56.

McMurray, A. (2007). Measuring Intercultural Sensitivity of International and Domestic College Students: The Impact of International Travel, Unpublished Thesis, University of Florida, Florida.

Mercan, N. (2016). Çok Kültürlü Ortamlarda Kültürel Zekanın Kültürlerarası Duyarlılık ile İlişkisine Yönelik Bir Araştırma, Niğde Üniversitesi İktisadi ve İdari Bilimler Fakültesi Dergisi, 9(1): $1-13$.

Mrekajova, E. (2018). Bir Yabancı Karşısında: Etkili Kültürlerarası İletişim İmkanlarının Değerlendirilmesi: Bursa Uludağ Üniversitesi Örneği, Yayınlanmamış Yüksek Lisans Tezi, Bursa Uludağ Üniversitesi, Bursa.

Öğüt, N. ve Olkun, E.O. (2018). Üniversite Öğrencilerinin Kültürlerarası Duyarlılık Düzeyi: Selçuk Üniversitesi Örneği, Selçuk İletişim, 11(2): 54-73.

Özdemir, İ. (2011). Kültürlerarası İletişimin Önemi, Folklor/ Edebiyat, 17(66): 29-38. 
Öztürk, A. (1999). İletişim Sistemleri ve İletişim Teorisi, Selçuk Üniversitesi İletişim Fakültesi Akademik Dergisi, 1(1): 58-69.

Rengi, Ö. ve Polat, S. (2014). Sınıf Öğretmenlerinin Kültürel Farklılık Algıları ve Kültürlerarası Duyarlılıkları, Zeitschrift für die Welt der Türken Journal of World of Turks, 6(3): 135-157.

Tabachnick, B. and Fidell, L. (2013). Using Multivariate Statistics, Boston: Pearson.

Üstün, B. (2005). Çünkü İletişim Çok Şeyi Değiştirir!, Atatürk Üniversitesi Hemşirelik Yüksekokulu Dergisi, 8(2): 88-94.

Yağbasan, M. (2010). Kültürlerarası Etkileşim Bağlamında Türkçe ve Yunanca'daki Ortak Sözvarlı̆̆ının Değerlendirilmesi, Fırat Üniversitesi Sosyal Bilimler Dergisi, 20(1): 367-388.

Yeşil, S. (2013). Kültür ve Kültürel Farklılıklar: Liderlik Açısından Teorik Bir Değerlendirme, Elektronik Sosyal Bilimler Dergisi, 12(44): 52-81.

Yılmaz, F. ve Göçen, S. (2013). Sınıf Öğretmeni Adaylarının Kültürlerarası Duyarlılık Hakkındaki Görüşlerinin Farklı Değişkenlere Göre İncelenmesi, Adryaman Üniversitesi Sosyal Bilimler Enstitüsü Dergisi, 6(15): 373-92.

Zhu H. (2011). From Intercultural Awareness to Intercultural Empathy, Canadian Center of Science and Education, 4(1): 116-119. 